January 2018

\title{
Finding Moments of Meaning in Undergraduate Education: How the Scholarship of Teaching and Learning Can Help
}

Jeffrey L. Bernstein

Eastern Michigan University, jeffrey.bernstein@emich.edu

Follow this and additional works at: https://digitalcommons.georgiasouthern.edu/ij-sotl

\section{Recommended Citation}

Bernstein, Jeffrey L. (2018) "Finding Moments of Meaning in Undergraduate Education: How the Scholarship of Teaching and Learning Can Help," International Journal for the Scholarship of Teaching and Learning: Vol. 12: No. 1, Article 2.

Available at: https://doi.org/10.20429/ijsotl.2018.120102 


\title{
Finding Moments of Meaning in Undergraduate Education: How the Scholarship of Teaching and Learning Can Help
}

\begin{abstract}
I argue for the value of high-impact educational practices as tools to minimize the commoditization of higher education. As a vehicle for doing so, I discuss a travel course to Washington, D.C. that I have led. This course is a significant and meaningful learning experience for the students who participate. In reflecting upon the value of this course, I suggest that scholars of teaching and learning have a particular responsibility to resist the increasing commoditization of higher education. Instead, we must think about embedding significant and transformative elements into the curriculum. Scholars of teaching and learning must help to demonstrate, in our research and in our advocacy work, the value of this work for the learning and transformation of our students. We must work, almost as lobbyists and campaigners, to enhance the perceived value of these experiences in the higher education marketplace.
\end{abstract}

\section{Keywords}

Keywords: commoditization of education, travel courses, high-impact practices, policy

\section{Creative Commons License}

(c) (i) $\ominus$

This work is licensed under a Creative Commons Attribution-Noncommercial-No Derivative Works 4.0 License.

\section{Cover Page Footnote}

I am grateful to Eastern Michigan University, and particularly Jenifer Stanko, for their support of this teaching endeavor. I thank Randy Bass and Ron Delph for helpful conversations that stimulated my thinking about how to structure the course. Andrew Abad, Hailey Huckestein, Steven Mikulic, Nino Monea, Gary Poole, Michael Smith, and Brian Walsh all read the manuscript and offered useful and constructive feedback, for which I am most appreciative. Mitch Balish helped me work through one particularly challenging issue in presenting my argument. My biggest debt is to the students who have traveled with me, inspired me, and taught me so much before, during, and after the course. Their good cheer and dedication helped me in my search for meaning through//out this entire experience. 


\title{
Finding Moments of Meaning in Undergraduate Education: How the Scholarship of Teaching and Learning Can Help
}

\author{
Jeffrey L. Bernstein \\ Department of Political Science, Eastern Michigan University, Ypsilanti, MI 48197, USA
}

(Received 3 May 2017;Accepted 12 September 2017)

\begin{abstract}
I argue for the value of high-impact educational practices as tools to minimize the commoditization of higher education. As a vehicle for doing so, I discuss a travel course to Washington, D.C., that which I have led. This course is a significant and meaningful learning experience for the students who participate. In reflecting upon the value of this course, I suggest that scholars of teaching and learning have a particular responsibility to resist the increasing commoditization of higher education. Instead, we must think about embedding significant and transformative elements into the curriculum. Scholars of teaching and learning must help to demonstrate, in our research and in our advocacy work, the value of this work for the learning and transformation of our students. We must work, almost as lobbyists and campaigners, to enhance the perceived value of these experiences in the higher education marketplace.
\end{abstract}

\section{INTRODUCTION}

Higher education faces numerous challenges across the globe. The continuing struggles of the world economy leave less money available for colleges and universities; moreover, as political decision-makers question the value of higher education, their willingness to earmark funds for this purpose seems to be shrinking (for an example of questioning by a political figure, see Bennett and Wilezol, 20I3). Policy-makers increasingly seek "efficiency" in making funding decisions for higher education, leading us into discussions of MOOCs, or "credentialing," or other ways to address inefficiencies in higher education funding. Furthermore, at every level, the college experience is being equated almost entirely with helping students get better (paying) jobs when they graduate. Conversations that suggest eliminating liberal arts departments, or more generally cutting programs that do not directly prepare students for jobs, should concern academics.

To be clear, nobody disputes that students should emerge from college with greater access to higher paying jobs, nor that the jobs factor should be somewhat of a motive for attending college, or choosing what field of study to pursue. In times of global economic uncertainty, getting a job when one leaves college should be of significant concern. Nor should we dispute that colleges must operate in an efficient manner, particularly in times of scarce resources. However, neither the need to prepare students for the job market, nor the need to operate with maximum financial efficiency, should be the sine qua non in judging the effectiveness of a system of higher education. We are not attempting to churn out the maximum number of widgets at minimal cost. We are instead educating the global citizens of the future (Smith, Nowacek, \& Bernstein, 20l0).We are teaching them content, and helping them to become experts in some field of study. We are also, I would add, helping them to find their place in the world, to see who they want to be, and ideally to find how they can use their talents for the good of the world. Such a role, I argue emphatically, is well within the purpose of the modern university (Smith, Nowacek, \& Bernstein, 20l0).

The literature on high-impact practices shows us that institutions of higher education can achieve these lofty goals. Kuh (2008) and Brownell and Swaner (2010), for example, discuss high impact practices, including first-year seminars, learning communities, writing-intensive courses, collaborative practice, undergraduate research, and service learning. A report produced by the Association of American Colleges \& Universities' LEAP Project (2007) suggested that these types of practices are likely to lead to higher levels of student learning and development than regular classroom work.Any gain from these high-impact practices, however, comes not just from implementing them, but rather from implementing them well (Kuh, 2008).

This paper is motivated by the language of high-impact practices and the hope that these practices can provide students with meaningful, transformative experiences. I discuss a particular high-impact experience: a travel course in which I brought a group of students to Washington, D.C., to study American politics. I use this course to suggest a different model for higher education (or, at the very least, an enhancement of the best parts of our current models). Instead of a concentration on the job market, or on fiscal efficiency, I suggest that we consider the value of higher education in terms of the opportunities it provides to help our students find deeply meaningful moments. These experiences shape the collegiate experiences our students have. I also discuss how we can enable our higher education institutions to afford these experiences, and how we can encourage our stakeholders to value them and thereby encourage their proliferation.

I note at the outset that this is not a traditional SoTL study; I have not collected extensive evidence of the effect my practice has had on student learning. The data presented here are anecdotal, not systematic.' The scholarship of teaching and learning enters into this piece, rather, as a vehicle by which my argument about moments of meaning can be subjected to more rigorous

I. I would not dismiss these anecdotal data out of hand. In the hands of an experienced teacher, even anecdotal data about teaching and learning can be meaningful. Having seen what it looks like when students are not engaged by material-more times than I care to admit-I believe myself to be well positioned to know when I see moments of engagement. I note Supreme Court Justice Potter Stewart's well-known definition of obscenity, "I know it when I see it" (Jacobellis v. Ohio 1964). While this study does not make extensive use of objective data to test its claims, I am currently thinking through issues of how to do this in future iterations of the travel course. 
testing, and shared across teaching contexts to encourage others to pursue these moments of meaning. The language of SoTL can provide us a basis to argue empirically for the value of these experiences, and to demonstrate to our skeptics that they are worth doing. As such, the recommendations I offer speak largely to the scholarship of teaching and learning community. This paper argues for the role SoTL should play in the broader landscape of higher education.

\section{The search for meaning in Washington, D.C.}

In his book detailing the process of building the Vietnam Veterans Memorial (Scruggs \& Swerdlow, 1985), Jan Scruggs, the Vietnam veteran who was the driving force behind the memorial, told the story of a significant conflict that occurred shortly before construction began. A small but vocal minority had threatened to politicize the process and, by extension, derail moving ahead with building Maya Lin's provocative design for the memorial.The book writes of Scruggs going to the National Mall one night, when the conflict was at its most severe, and walking toward the Lincoln Memorial:

Scruggs looked up at Lincoln. The CivilWar had been America's bloodiest conflict, and yet this memorial carried no sense of violence. It was nonpolitical. Nothing favored the North or the South. Nothing said that slavery was morally wrong. Or that the Civil War was right. Like Maya Lin's design, it provided a sense of history, it was simple, and it relied on words. People could read Lincoln's Gettysburg Address and Second Inaugural Address, think about the words, stand quietly, and let the feelings flow. They could come away different than when they arrived. (p. 88-89, emphasis mine)

This story represents a touchstone for my work on travel courses and meaningful moments.

During my university's 2013 spring break, I took eighteen students on a travel course to Washington, D.C., to see this memorial, and many other sights. ${ }^{2}$ The upper-level political science course was entitled "Washington, D.C.: Rhetoric and Reality." I aimed to help students see the beautiful, soaring rhetoric of Washington (its buildings and monuments, its embodiment of our rich past in word and deed) and to attempt to reconcile that inspiring rhetoric with the ugly reality of bitterly divided partisan politics and political grandstanding (and with all of the homeless people they saw sleeping on the street). We were tourists, but we were also students meeting with influential Washington politicos, as well as doing academic reading and writing before and after the travel portion of the class.

This essay uses my reflections on that week (and, to a lesser extent, on iterations of this course done since then) as a catalyst for discussing how we can improve higher education. I argue that experiences like this course provide students an opportunity to find deeper meaning and value in their education. This is done when students make connections with their fellow students, see a world that is larger than what they usually get to see, and envision a future for themselves that extends beyond what they originally thought they could do. I believe now, even more strongly

2. On the value of travel courses for student learning, see Arcodia and Dickson (2013); Gomez-Lanier (2017), and Miao, Harris, \& Sumner (2005/2006). than before, that a search for meaning in their education needs to be undertaken by more students.

Like most academics, I see others who view the college degree as the instrumental pursuit of the magic number of credits needed to graduate and to get a high-paying job. The literature offers examples of how students today are not getting the education they ought to be getting, especially given what they and their families pay for the experience (e.g., Arum and Roksa, 20I I; Bok, 2006; Hacker and Dreifus, 20I0; Hersh and Merrow, 2005; Nathan, 2005). The blame for this may rest with those students who choose not to seek a deeper meaning in their higher education, viewing education solely as the accretion of credits. However, the fault also lies with our institutions, which too often market themselves mostly as a step toward financial gain, and with those who fund our public universities, who force schools to shortchange meaningful educational opportunities due to cost. Whether students' instrumental attitudes toward college are the cause or the result of problems in higher education, we know many students are disengaged throughout college. I am not the first professor to notice and lament this fate, nor will I be the last.

While I do exist in the world cited above, this paper offers an existence proof that this paradigm can be upended. I walk away from my travel courses knowing my students enjoyed a meaningful week. When I was reading Scruggs' book while struggling with this essay, the quotation above stuck out to me. Ultimately, I hoped students would come away from the trip different than when they arrived, a standard against which we might measure a high-impact practice. Taking the idea a step further, I want my students, and all of our students, to be able to say the same about their college education. ${ }^{3}$ That hope, and the significant impact the scholarship of teaching and learning movement can play in making it a reality, animate this paper.

\section{The Challenge: Commoditization and Credits}

Even a casual observer of higher education would be struck by the increase in what Nelson (2009; see also Delbanco, 20I2; Noble, 1998) calls the commoditization of higher education. Economists define commodities as goods that are interchangeable with, and indistinguishable from, one another, regardless of how they are purchased.An ounce of gold, for example, is a commodity - gold is gold, no matter where and how one purchases it. Thus, rational consumers are motivated by price and/or convenience in determining where to purchase gold, as the product will be the same no matter where and how it is purchased. In this context, Nelson (2009) asks us to consider a college course as a commodity. If an Introduction to Sociology course easily transfers from one institution to another and "counts" the same at any school, and if we assume the course is basically the same no matter where one takes it, a rational higher education consumer should consider only price and convenience in determining where to take the course. If the

3. In truth, most of my faculty and administrative colleagues want the same, but constraints of our jobs (i.e., limited time and financial resources) make pursuing these high-impact practices more difficult. Moreover, even in the face of these resource constraints, students often do experience these important moments of meaning. My argument here is not that these experiences do not exist, but rather that we need to do more to pursue and encourage them. 
course can be taken for less money, or more conveniently, in one place, the student should take the course there.

We all must confront this commoditization challenge. Why should we encourage students to take general education courses at the more expensive institutions where some of us teach when they might be able to take the course elsewhere for less money? An additional wrinkle on this challenge has been the increasing prominence of online education, and of MOOCs (Massive Open Online Courses). Why should a student make the effort to go to a brick and mortar classroom when they take a class online, from the convenience of their own home, and get the same credits for it? Why should my university offer an introductory American Government course, and desire that our students take such a course with us, when the content of a ready-made online module, taught by a professor at a more prestigious university, can so easily be accessed by our students? If we have no good reasons for students to take classes at their home schools, then perhaps they should not. If students make these decisions, the consequences could be severe for our institutions.

Implicit in the idea of the college course as a transferable good is that a college education is the accumulation of 120 credit hours, plus or minus (Schneider, 20I2). A college degree does mark the accumulation of some number of credits. Our students, who pay so much money for those credits, can be forgiven for thinking of their degree as a series of "hoops" through which they must jump; achieving the requisite number of credit hours may be the largest hoop of them all. When students struggle to find the courses they need offered in the term when they need them, when graduation requirements seem arbitrary, and when classes sometimes are poorly taught, students understandably think of education as the need to amass a set number of credits and then move on.

I fear, however, that some of our students may be accumulating these credits despite the absence of deeply meaningul academic experiences.Arum and Roksa (20I I), Bok (2006), Hacker and Dreifus (2010), and Nathan (2006) all point to this same disturbing conclusion. As students view their classes as obstacles, rather than as opportunities for deep learning and transformation, they cheat themselves out of a large part of the college experience. When we buy a commodity, we standardize our expectations about what we get - we "win" based not on the product (which will always be the same), but only on the price and manner of the purchase. But what if we change our approach? What if college courses (and the college experience in general) were not viewed as commodities, nor merely as steps toward a better job, but instead represented the possibility of deeply meaningful experiences? What if our language did more to encourage students to accumulate these moments of meaning? And, what if our institutions did more to compete in the higher education marketplace by trying to provide these deeply meaningful experiences, as a way to set themselves apart from other institutions and de-commoditize the process? ${ }^{4}$

\footnotetext{
4. One reviewer asks what would happen if de-commoditization becomes the new coin of the realm - what if, in other words, being the "meaningful experience" institution becomes the new commodity? I address this in two ways. First, this would be a fantastic problem for those of us in higher institutions to have; if all schools offer truly meaningful experiences, many complaints about higher education noted in the literature would be rendered moot. Second, truly mean-
}

The literature (e.g., Brownell and Swaner, 20I0; Kuh, 2008) shows that high-impact practices lead to better student outcomes. The Washington, D.C. course, which I describe in some detail below, is just one example of what high-impact practices can look like. My argument here is that we need to change our language around higher education from one of "credit accumulation" and "job training" to one of "searching for meaning" to fully encourage students to pursue them. We also must make these high-impact practices available to more students, despite many barriers our institutions confront in doing so. Doing so will not be easy; if my example is at all representative, however, it will be worth our efforts to make that happen. ${ }^{5}$

Participants in the scholarship of teaching and learning must spend more time going public with arguments about how these practices transform our students, and our institutions. Scholars of teaching and learning can lead our institutions to make these profound changes; ideally, we can also shape the educational marketplace to increase the perceived value of such meaningful experiences, thereby resisting commoditization. If people look to higher education and ask it only to provide fiscally prudent job training for our young citizens, they will be less likely to protest the commoditization, and the credit-driven approach, wis at the heart of my concerns. If, however, we encourage consumers of higher education to believe that this search for meaning is important, and if we can encourage them to demand it, we will empower our institutions to seek to provide this. My vision for higher education returns to Jan Scruggs and the Vietnam Veterans Memorial - how can we help our students leave college "different than when they arrived?" How can we help undergraduate education become not just the pursuit of credits, but also the pursuit of meaning? How can we overcome our weaknesses, and build on our existing strengths, to make this a reality?

\section{What Meaningful Experiences Can Look Like}

When my students and I travel to Washington, D.C., we are inspired by the words inscribed at the MLK, FDR, Jefferson, and Lincoln Memorials. We look at the U.S. Capitol Dome in the distance and see the hope and the potential for the American experiment with democracy. However, the reality of government is a good bit different. As Mann and Ornstein argue in It's Even Worse Than it Looks (20I2), which the class read and discussed before traveling, the hyper-partisanship, the posturing, and the "smallness" of contemporary politics can depress even the most optimistic of us (and this was before the 2016 election!). How can we reconcile the inspired rhetoric of Washington with the unseemly reality that exists inside the Beltway? This became one of the central discussion points in our course whenever I traveled; it forced students to think critically about these issues while experiencing the city firsthand.

To say the very least, the students had a wonderful time on our DC experience. When asked to rate the first iteration of the

ingful experiences are largely unique, and, as such, would be hard to standardize in the way that an introductory calculus class could be.

5. My Washington course is one example of a high impact course; I do not suggest that this course, or other travel courses, are the model for high-impact educational experiences. Many approaches, such as academic clubs, study abroad, internships, and peer instruction, yield desirable outcomes. 
class on a scale from I to 10 , with ten as the highest rating, the average rating was 9.14; half the students gave the course a 10 , and no rating was lower than 7 . These representative open-ended student comments reflect this general enthusiasm with the trip:

I loved seeing all of the memorials \& meeting with different people who had different views, loved all of the tours.

It was a valuable experience because of the amount of passion in the group.

I'm more intrigued about running for office and the judicial system now.

I felt overwhelmed with inspiration. I learned a ton and experienced a new place.

[The] trip was very valuable to me. I learned so much, and it's got me energized for the future. It showed that what we want to do in public service is possible, and we can be successful if we're passionate \& hard working.

There were a few negative comments about the trip, which generally addressed the length of the days (too long) and the amount of walking (too much). A couple of students did comment that they did not learn as much as they had hoped to, a concern I shared to an extent. ${ }^{6}$ All of these have been carefully considered as I have redesigned the course for subsequent offerings.

Beyond these generally favorable comments, the students shared with me many thoughts about favorite aspects of the trip. They commented about some of the "touristy" things we did, especially visiting the White House and the Supreme Court. They were inspired at the Changing of the Guard and the Laying of a Wreath at the Tomb of the Unknown Soldier, the gravesite of President John F. Kennedy, and at many of the memorials dotting the National Mall. ${ }^{7}$ In addition to the tourist attractions, students were affected by the time we spent talking to the people who are most connected to the political system today. These included political consultants from both sides of the aisle, highly placed legislative staffers, and prominent scholars of the political system. We heard pessimistic statements about government today (particularly the highly partisan nature of it), but also heard prominent people suggest that there is much more bipartisanship than the casual observer might see. Simultaneously (sometimes even within the same conversation) we found reason to hope, and reason to despair.Washington frustrated - and Washington inspired.

In class, and on the trip, I frequently remind my students that the opposite of love is not hate - it is apathy. If students hate an assigned reading or argument, I can work with that. I can use their unhappiness to the benefit of the class, by having students engage arguments across difference. When students are apathetic about a reading, or do not care to hear what others

6. This concern reflects a tension within the course design. The course is both a tour of a fabulous city and a serious academic course. I struggled with the tension of trying to be true to both facets the first time I offered the course, and continue to struggle with it in future iterations. I would like to think that I am improving this balance the more I teach travel classes. Perhaps I am.

7. The Korean War Memorial merited particular mention from my students. are saying, my job becomes difficult. Teaching a group of students who are fired up by the material - whether they love it or hate it - is infinitely easier than teaching students who just don't care.

I am not naïve enough to suggest that every student was engaged by every moment of the course. However, when I think back on the trips, and reminisce with students, I have many positive memories of students deeply engaged in learning. There are a few negative memories (the perceived rudeness of the U.S. Capitol Police, and the aggressiveness of one particularly hardnosed partisan figure with whom we met, generated the bulk of these negative recollections). However, even the negativity provided valuable learning opportunities. Deconstructing the combative, hyper-partisanship of our least-popular speaker provided opportunities for students to explore the positives and negatives of a "team-based" (i.e., partisan) political system. Even the encounters with the Capitol Hill police offered the opportunity to remind students of Gabby Giffords and the fact that members of Congress are correct to view themselves as potential targets for violence. ${ }^{8}$ This led to interesting and sobering discussions about the intense (and sometimes scary) nature of contemporary politics. In our best moments, and in our worst moments, students engaged the material in a meaningful way. Such engagement, I would argue, is a prerequisite for those profoundly meaningful moments suggested by the Scruggs quotation at the start of this paper.

\section{Facilitating the Search for Meaning}

With the benefit of time to reflect, I continue to believe that this trip was a highly meaningful educational experience for my students. They had an opportunity to see a city that half of them had never seen before (and that many others had only seen briefly, often as part of a short middle school or high school trip). The students had a chance to meet with people with whom they would not normally interact, and to see themselves as potentially filling their positions one day. Students considered larger national issues, including some of our most intractable problems, and left with hope. I was inspired, and continued to be inspired, by their enthusiasm, their pursuit of social justice (from a variety of perspectives), and by their sincere desire to be part of the solution our nation needs. The numbers of them who are going (or have gone) into public service, and relate their desire to do so to what they learned when we traveled together, is both startling and exciting.And, the number who continue to tell me how much the trip meant to them, and how important it has been to their way of viewing the world, has been shockingly high as well.

I would not argue that this course provided the only opportunity for engagement that my students will experience in college. The students I brought to Washington are engaged in a

8. Former Congresswoman Gabrielle Giffords (D-Arizona) was shot (along with a member of her staff and members of the public) while she was meeting with constituents outside a grocery store in 201 I. Giffords survived the shooting, although she was wounded severely; six people died, and thirteen others were wounded (including one wounded while subduing the attacker). The shooting of House Majority Whip Steve Scalise (R-Louisiana), along with a Capitol Hill staffer, lobbyist, and two members of the U.S. Capitol Police, in June 2017 is another reminder that security concerns for members of Congress (and other government officials) are warranted. 
wide variety of meaningful learning experiences - some of them have participated in Model United Nations, Mock Trial, and study abroad programs. Many have had internships that shaped what they want to do when they leave college. Some have participated in particularly meaningful in-class simulations, or successful group projects, or done independent study projects with professors. Many are campus leaders. This reflects a self-selection process; students who would give up their spring break and pay money for an additional course and a course fee to travel to Washington with a professor are the students who would already have been doing these aforementioned activities.

These students clearly have rejected the view of college as just the search for the credits they need to graduate. Instead, they crave knowledge, and deep, meaningful, life-changing experiences. What if more students were like this? Would our classes, and our institutions, change? Would we view our jobs differently if we saw more of our students not as lazy millennial slackers but instead as idealistic young people looking for an opportunity to make their mark on the world? Obviously, the possibilities here represent false dichotomies. Some students are well aware that they can do college quicker, cheaper, and easier, and yet still insist on taking harder classes and programs of study, engaging in time-consuming activities, and rejecting these negative stereotypes. Even many of the most disconnected and disinterested students might want to come away with deep learning and significant, meaningful experiences, at least on occasion. ${ }^{9}$ So, how do we make the desire for meaningful learning experiences universal and achievable?

One approach to this challenge is to organize our colleges and universities to help students find these meaningful learning experiences. Universities could require students to participate in an "Engaged Learning Experience," which could be fulfilled through a study abroad semester, or a travel course, or an internship, or even a particularly meaningful experience like a simulation-based course. Most universities do something similar to this, albeit usually in a format that is easier to fulfill, and less likely to promote deep learning. While far better than nothing, such a requirement would quickly be viewed as one more part of the credit-based set of graduation requirements (i.e., "This term, I need to complete my last science course, two more courses for my major, one for my minor, and my engaged learning experience.") We need to do more than this.

If we desire to push students toward highly meaningful educational experiences, how can we facilitate this? I argue that we need to consider three particular aspects of this facilitation. First, we need to consider simple economics - how can our universities afford to make these experiences available to students in our fiscally challenged times? Second, we need to ensure that faculty have the support necessary to make this work possible. Our schools must find institutional arrangements to support innovative teaching, and to have such work "count" for faculty who are weighing the plusses and minuses of engaging this work in the calculus of their careers. Finally, we must consider how to document and argue for the impact of these practices, in an effort to get more colleges to support the work, and to encourage the public to weigh the abilities of colleges and universities to

9. Moreover, to be fair, even our most dedicated students do go through some times when they do not put forth their best efforts and merely seem to be going through the motions. provide for these experiences in determining the relative value of schools. While achieving success in these three areas will be difficult, the consequences of failure are significant.

First, we need to find ways to fund these high-impact practices more. Approximately half of the students who travel to Washington with me receive financial aid to do so. I shudder to think of the other students who might have wanted to take this trip but could not afford the relatively modest program fee (about $\$ 900$, plus minor out-of-pocket expenses, in addition to the cost of a three-credit class) in addition to a week of lost wages from their jobs while traveling. While I would hate to think that I am working so hard to offer an opportunity only to the "haves" and perpetuating the existing socio-economic biases in higher education, I know that, ultimately, I am.

To prevent this from happening, we need to undertake significant efforts to support these endeavors for students. As higher education goes through funding crises, universities will struggle to fund these efforts on their own. Instead, we may need to seek private support. Faculty (overworked as we are) should work with development officers at our institutions to identify donors who can see the value of Mock Trial, or Model UN, or internships, or study abroad, or travel courses, and who will put money behind these efforts. Let our students tell the donors how much their lives were enhanced by travel opportunities, or extra-curricular academic pursuits, and try to find more support for these activities. To be sure, universities must put some money behind their institutional commitments - if a school believes it should encourage its students to have these meaningful experiences, it must find money to seed these initiatives. If these seeds are to blossom, however, we may need to find unconventional ways to support them. ${ }^{10}$

Second, we must explore ways for our universities to support innovative teaching arrangements. Large numbers of faculty seek to engage in unconventional arrangements such as team-teaching an interdisciplinary course, or incorporating service learning or active learning into their classes, or developing travel courses. In many schools, however, logistical challenges mitigate against this. For example, how should we "count" team teaching in terms of faculty workload? How are faculty who add to their teaching burdens by incorporating an academic service-learning project to be given the resources to complete the project successfully? Will innovative teaching "count" for tenure and promotion, above and beyond just being effective in the classroom? It is far beyond the scope of this essay to tell institutions how they should answer these questions; answers depend on the specific institutional context. " However, it is very much within the scope of this essay to say to our institutions, "If you value these meaningful educational experiences for your students, and you should, then you must find ways to support and enable these experienc-

10.When seeking outside funding, we must be aware of the risks of allowing outside donors too much power in academic affairs. Universities must retain control of the content of such programs, even as we seek outside funding to support them.

I I. The Imagining America/Campus Compact initiative on validating civic engagement as part of promotion and tenure represents one model worth further exploration. Furthermore, Huber (2004) offers a set of biographies of faculty who have managed, within their different institutional contexts, to make room within their career to do significant work in SoTL. 
es, and to credit faculty for supporting them in your tenure and promotion decisions."

Third, and most critically, scholars of teaching and learning need to continue to document the impact of these experiences and to argue for their worth in the marketplace of higher education. The bulk of scholarship of teaching and learning studies focuses on student learning in individual classes; such work is important, and must continue. However, as potential leaders in higher education, we must continue to do, and to go public with, work that documents the significant value of educational experiences such as being part of competitive academic teams, or studying abroad, or taking travel courses. We need to continue to connect our work to major innovations in the scholarship of teaching and learning, and to push educational policymakers and stakeholders to find ways to support these practices. ${ }^{12}$ While instructors can be strong advocates for these experiences, there is little doubt that students can be some of our best advocates (and, as Werder and Otis [2009] demonstrate, some of our best collaborators) in these efforts.

Our role as faculty goes further. When the marketplace increasingly commoditizes higher education, institutions that provide meaningful educational opportunities offer significant value-added over their competition. We leverage this competitive advantage by participating in the conversation about what a good college experience looks like.As faculty, we have an obligation to speak out against policymakers and others (including some of our own administrators) who encourage prospective students (and their parents) to view college solely as preparation for the job market. We must advocate for the purpose of higher education being to help students learn and grow, and to help them seek meaning through their college education. Can we alter the decision-making calculus of future students by helping them see what really matters in college?

Since this essay focused on a political science course, I will use one additional analogy, drawn from the political world. Constance Cook, retired Executive Director of the Center for Research on Learning and Teaching at the University of Michigan (and a fellow political scientist), has argued that much of her role in directing the teaching center is that of a lobbyist:

I consider myself the chief lobbyist on campus for teaching improvement, and the strategies I use - such as coalition building, data gathering and dissemination, and logrolling mirror the ones the lobbyists use in local politics, state politics, and Washington, D.C. (Cook, 20I I, p. 19-20). ${ }^{13}$

Political scientists understand lobbyists to be passionate advocates for their causes (Berry \& Wilcox, 2008). In Washington, my students spoke with people committed to causes, and willing

12. This can involve work on SoTL applied outside the classroom (McKinney, 20I2), for example, as well as on how SoTL can connect with other institutional initiatives such as program assessment and community building (Rehrey, Siering \& Hostetter, 20I4). It can also involve SOTL scholars, or faculty developers, playing an advocacy role on campus (Bernstein, 2013; Cook, 201 I).

13. Referencing Cook, and the work of teaching centers, offers a reminder that we are not alone in our efforts. The scholarship of teaching and learning offers some leverage for these conversations that need to occur, and faculty engaged in this work are natural collaborators. In addition, faculty developers are key allies (among others) who can help us to achieve our goals. to do everything they could to achieve their goals. Policy change in Washington requires this commitment and passion. If scholars of teaching and learning believe meaningful educational experiences are important, we must passionately advocate for them, using the strategies and skills that lobbyists use on a daily basis to convince others of the validity of our arguments.

Effective lobbyists know that sometimes one does not need to change opinions as much as change priorities. Sometimes, this involves convincing the masses that they value something they did not know they valued. For example, we ought not to judge a college, and its courses, solely based on cost and convenience (although these factors do matter a great deal); instead, we should also ask questions about how schools can provide opportunities for students to experience moments of meaning in their education. As an academic and as a tuition-paying parent, I value this aspect of the collegiate experience (and tried to help my son do the same as he made his college choice). However, I am not sure many of our targeted students and parents do this to the same extent. Can we help them see the potential benefits of college that we see?

I would urge my fellow academics, especially leaders in the scholarship of teaching and learning movement, to take on the daunting task of altering mass opinion. We can do this on a small scale, in our conversations in our communities. Can we volunteer at our institutions to meet with prospective parents and students, helping them to see the possibilities that college can offer them, and encouraging them to pursue these possibilities? How much the better it would be if we can honestly steer them to the schools at which we work for these opportunities! Can we add our wisdom and perspective to the voices in the public square discussing higher education, making the types of arguments I suggest here? It will be difficult. Nevertheless, if we do not, very few commentators on higher education will take on this task for us.

Higher education should not exist solely to prepare students for jobs. At the end of the day, we also exist to prepare students to be responsible members of their communities, to be global citizens, and to be motivated toward (and skilled at) working for change in the world. Where possible, providing students with meaningful opportunities to learn our course material more deeply, to make connections that were previously unseen, to forge connections with other students and faculty, and to undergo deep personal change and growth, should be an ultimate goal. Doing this is an ambitious target; such work is not easy. However, given a competitive higher education market and a society that desperately needs our youth to become a well-educated citizenry prepared to assume positions of leadership, the work is essential.

\section{CONCLUSION - STUDENTS WERE NOT THE ONLY ONES WHO CAME AWAY DIFFERENT}

I decided to teach this course because I love Washington, D.C., and wanted to share the city that I love with my students. I wanted to walk around the Memorials with a group of students who really wanted to be there. I wanted to see their faces as they saw the inside of the Jefferson Memorial, and as they sat in the Senate gallery and saw political celebrities like John McCain and Harry 
Reid walk onto the floor. I wanted to see what kinds of interesting political discussions this city could provoke; I wondered if we could have a more intelligent discussion of the role of the Supreme Court after the students had just spent time in the courtroom, and in the building. Would we have great discussions over dinner, or in the hallways of the Hotel Harrington, comparing how Republican and Democratic consultants analyzed the 2012 presidential election? The answer is that we could, and we did. While it is hard to generate hard data to show that this happened, the long discussions on the trip that continue to this day indicate that the class was engaged and excited by what they saw. Our group built upon our shared experiences to raise the level of political discourse - there would have been no way to replicate this experience in a classroom on campus.

Teaching, as we know, is hard work. For every positive moment, it sometimes seems as if we have even more challenging moments.We struggle to keep up with all we have to do - to stay current in our fields, keep our classes fresh, grade those annoying papers, attend all our committee meetings, and meet with students. While we have good lives (the worst day as a professor is better than the best day doing many other jobs), we sometimes find ourselves lacking in fulfillment.

Then, sometimes, we get these kinds of experiences. We get to work closely with students who energize and engage us. We see what they are capable of - and we see them learning what they are capable of.We get the opportunity to interact informally with our students over meals, or at breathtaking sites - and then we return home to build upon the close relationships forged while traveling together. This trip has validated me, yet again, in my career choice. I had the opportunity to work with, and learn from, an extraordinary group of students, in an extraordinary setting.

I began this essay by suggesting that some of the sites in Washington leave visitors different than they were before they arrived. I have no doubt my students experienced that at some of the tourist sites they visited, and that they experienced this in a larger way on the whole trip. I know that even after seeing some of the sights for perhaps the tenth time in my life, I have come away from them different than I was before seeing them this last time, in large measure because of who I traveled with and because of our shared experiences that went into each site. I, and my students, were fortunate to have this enriching opportuity. I conclude this essay with my fondest hope that our universities will react to the call in this paper to find ways to help more students have moments like this. To help this happen, I would like nothing better than to see faculty (and students) use the methods and intellectual traditions of the scholarship of teaching and learning to speak out about the value of these experiences and to help others see that college should be about the accumulation of them. It is all of our responsibilities to help students emerge from their college years different than they were when they arrived.

\section{Acknowledgements}

I am grateful to Eastern Michigan University, and particularly Jenifer Stanko, for their support of this teaching endeavor. I thank Randy Bass and Ron Delph for helpful conversations that stimulated my thinking about how to structure the course. Andrew Abad, Hailey Huckestein, Steven Mikulic, Nino Monea, Gary Poole, Michael Smith, and Brian Walsh all read the manuscript and offered useful and constructive feedback, for which I am most appreciative. Mitch Balish helped me work through one particularly challenging issue in presenting my argument. My biggest debt is to the students who have traveled with me, inspired me, and taught me so much before, during, and after the course. Their good cheer and dedication helped me in my search for meaning throughout this entire experience.

\section{REFERENCES}

Arcodia, C., \& Dickson, C. (20I3). Tourism field studies: Experiencing the carnival of Venice. Journal of Hospitality and Tourism Education, 25(3), I46-I55.

Arum, R., \& Roksa, J. (20I I). Academically adrift: Limited learning on college campuses. Chicago: University of Chicago Press.

Association of American Colleges \& Universities. (2007). College learning for America's new century. National Leadership Council for Liberal Education and America's Promise.

Bennett, W.J., \& Wilezol, D. (20I3). Is college worth it? A former United States secretary of education and a liberal arts graduate expose the broken promise of higher education. Nashville: Thomas Nelson.

Bernstein, D. (20I3). How SoTL-active faculty members can be cosmopolitan assets to an institution. Teaching \& Learning Inquiry I(I), 35-40.

Berry, J.M., \& Wilcox, C. (2008). The interest group society, $5^{\text {th }}$ ed. New York: Pearson.

Bok, D. (2006). Our underachieving colleges: A candid look at how much students learn and why they should be learning more. Princeton: Princeton University Press.

Brownell, J.E., \& Swaner, L.E. (2010). Five high-impact practices: Research on learning outcomes, completion, and quality. Association of American Colleges \& Universities.

Cook, C.E. (20I I). Leading a teaching center. In C.E. Cook \& M.L. Kaplan, (Eds.), Advancing the Culture of Teaching on Campus: How a Teaching Center Can Make a Difference. Sterling, VA: Stylus Publishing.

Delbanco, A. (20I2). College:What it was, is, and should be. Princeton: Princeton University Press.

Gomez-Lanier, L. (2017). The experiential learning impact of international and domestic study tours: Class excursions that are more than field trips. International Journal of Learning and Teaching in Higher Education 29( I), I29-I44.

Hacker, A., \& Dreifus, C. (2010). Higher education? How colleges are wasting our money and failing our kids--and what we can do about it. New York: St. Martin's.

Hersh, R.H., \& Merrow, J., eds. (2005). Declining by degrees: Higher education at risk. New York: Palgrave Macmillan.

Huber, M.T. (2004). Balancing acts:The scholarship of teaching and learning in academic careers. Sterling,VA: Stylus.

Kuh, G.D. (2008). High impact practices: What they are, who has access to them, and why they matter. Washington:Association of American Colleges \& Universities.

Mann,T.E., \& Ornstein, N.J. (20I2). It's even worse than it looks: How the American constitutional system collided with the new politics of extremism. New York: Basic Books.

McKinney, K. (20I2). Making a difference:Application of SoTL to enhance learning. Journal of the Scholarship of Teaching and Learning I 2(I), I-7.

Miao, S.Y., Harris, R., \& Sumner, R. (2005/2006). Exploring learning 
during study tours. International Journal of Learning I 2(II), 55-62.

Nathan, R. (2005). My freshman year: What a professor learned by becoming a student. Ithaca: Cornell University Press.

Nelson, Craig E. (2009).Why SoTL? Why Now? Keynote Address presented at the 2009 Annual Conference of the International Society for the Scholarship of Teaching and Learning, Bloomington, Indiana.

Noble, D.F. (1998). Digital diploma mills: The automation of higher education, First Monday 3(I).

Rehrey, G., Siering, G., \& Hostetter, C. (20I4) SoTL principles and program collaboration in the age of integration. Interna- tional Journal for the Scholarship of Teaching and Learning 8(I), Article 2.

Schneider, C.G. (20I2). Is it finally time to kill the credit hour? Liberal Education 98(4), 2-3.

Scruggs, J.C., \& Swerdlow, J.L. (1 985). To heal a nation:The Vietnam Veterans Memorial. New York: Harper and Row.

Smith, M.B., Nowacek, R.S., \& Bernstein, J.L., eds. (2010) Citizenship across the curriculum. Bloomington, IN: Indiana University Press.

Werder, C., \& Otis, M., eds. (2009). Engaging student voices in the study of teaching and learning. Sterling,VA: Stylus Press. 